\title{
APPLICATIONS OF ARTIFICIAL INTELLIGENCE IN MEDICINE AND PHARMACY - ETHICAL ASPECTS
}

\author{
Emilija J. Kostić1,2, Dimitrije A. Pavlović1, Miroslava D. Živković1,3
}

\begin{abstract}
In the last 30 years the development of artificial intelligence (AI) that can be applied in all areas of science has brought numerous benefits. Many researchers have explored potential applications of intelligent techniques in every field of medicine. The importance of AI is reflected in the possibility of proper decision-making, without subjectivity, fatigue, with unlimited possibilities of remembering and making conclusions. This is important in medicine, for the prevention and diagnosis of various diseases, as well as therapy monitoring. Numerous studies have shown that AI will soon replace medical staff in numerous activities, as results obtained by AI are better and more precise. A number of applications have been developed to simplify patient adherence to therapy, which ultimately affect the therapy. The application of AI is present in the pharmaceutical industry, in the design of new drugs. This precludes preclinical tests, which are extremely long and expensive. AI makes conclusions based on the available data, so the validity of data must be taken into account because extremely important algorithms are based on them. An important aspect is the protection of patient data since the possibility of data becoming public is a major ethical problem. Computers and AI are the cause why many people are replaced at their jobs, and the tendency is that such a trend continues. The question arises whether the machines should replace people in areas such as medicine, where feelings, empathy, and warmth are very important factors.
\end{abstract}

Acta Medica Medianae 2019;58(3):128-137.

Key words: artificial intelligence, medicine, pharmacy, applications, ethics

${ }^{1}$ University of Niš, Faculty of Medicine, Niš, Serbia

${ }^{2}$ Institute of Forensic Medicine Niš, Niš, Serbia

${ }^{3}$ Clinical of Neurology, Clinical Centre of Niš, Niš, Serbia

Contact: Emilija Kostić

Blvd dr Zoran Djindjić 81, 18000 Niš, Serbia

E-mail: emilija293@gmail.com

\section{Introduction}

For centuries, there was a distinction between man and the rest of the natural world as well as human domination over the rest of the living world. This distinction is seen in the capability of learning, concluding and making decisions. The logic and ability of inductive thinking make the human brain superior to the most advanced computer. As a result of man's desire to produce software that, like the human brain, would be able to solve complex, sophisticated problems in an intelligent way, artificial intelligence (AI) was created (1).
The importance of intelligent agents nowadays

AI is the main issue of the contemporary world. Every day people can hear about its achievements in the most diverse areas of science, technology, even art, and entertainment. AI considers thinking, making decisions, navigating in new situations for computers or machines. Computers can run 24 hours a day, without tiredness, loss of concentration, without prejudice, and the amount of information that can be processed per unit of time is disproportionately greater (the computer that defeated Chess Grandmaster Kasparov had the ability to estimate 200 million moves per second). Also, they do not die; their knowledge remains forever, unlike the knowledge of a human that disappears after their death.

The idea of an ideal machine that will have the capability of thinking comes from the ancient time, but the conception of AI was introduced by John McCarthy in 1956 (2). Great progress in this area has been remarkable in the last 60 years. It was conditioned by discoveries in the field of neuroscience, cognitive psychology, information technology, statistics, mathematics, cybernetics, and logic. There are tendencies to secure progress in the future. AI refers to artificial neural networks (ANN), fuzzy ex- 
pert systems (FES), evolutionary calculations (EC), and hybrid intelligent systems (HIS) (3).

The "thinking" of a computer is based on algorithms, which represent the steps in that process, similar to solving a puzzle. Very often, people use intuition to solve the problem, and views on the effectiveness of the use of intuition are varied and often conflicted (3).

\section{Potential applications of AI in solving some of the global health problems}

The health and well-being of every human being is a priority of the modern world. There is a constant need for the promotion of health and disease prevention, of both chronic and acute conditions. There are diseases that medicine has eradicated, for example through the usage of vaccines, but on the other hand, there are new diseases, new infectious agents; the number of cancer patients and patients with metabolic diseases is on the rise. Data from the World Health Organization on the number of people with diabetes: in 2016, there were 422 million people affected, while in 2013 it declined to 381 million.4 Data collected in the period from 2008 to 2012 on the incidence of cancer: 454.8 patients per 100,000 inhabitants and mortality: 171.2 deaths per 100,000 inhabitants per year (5).

The number of HIV-infected people is 36.7 million, of which 2.1 million children under the age of 15, according to data from the end of 2016 (6). There are diseases that can be controlled by adequate drug therapy; life expectancy with adequate therapy is prolonged, but the quality of life of patients must also be considered. The achievements of modern medicine and pharmacy from the invention of aspirin and penicillin until today are high, but further progress is also necessary.

From the middle of the last century, researchers have explored the potential applications of intelligent techniques in every field of medicine.

The application of AI technology in the field of surgery was first applied by Gunn in 1976, for diagnosing the cause of acute abdominal pain by computer analysis (7). The last two decades have seen a growing interest in the medical application of AI. Modern medicine faces the challenge of analyzing and applying a large amount of acquired knowledge in order to solve complex clinical problems. The development of medical AI was linked to the development of AI programs to help the doctor make a diagnosis, make therapeutic decisions, and predict the outcome. They are designed to ease the daily work of health care workers, specifically in tasks that rely on manipulation of data and knowledge, because empathy, support, and human warmth cannot be replaced by artificial systems (8).

\section{Artificial neural networks}

Artificial neural networks (ANNs) are computer programs designed to simulate some of the functions of the human brain such as learning, the abi- lity of generalization and concluding based on prior experiences (1).

Based on the number of published papers in the field of application of AI in medicine, it is easy to conclude that the most important is ANN. ANNs are designed to solve various problems where classical methods do not yield satisfactory results. The basic principle taken from nature is that the nervous system processes the information processing with the help of simple process units - neurons. The basic principle from nature is that the nervous system processes information through simple process units neurons. Another blueprint taken from nature is the system's ability to learn. ANNs are not programmed, they learn by observing a number of examples of solved problems. Using different learning algorithms, they detect links and templates within a group of data presented to them, thus gaining the ability to anticipate responses to new experimental conditions (1).

It is the ability of neural networks to generalize the problem, learn from memorized examples, analyze non-linear data, handle imprecise information by enabling the application of independent data model that makes them a very attractive analytical tool in the field of medicine $(1,8)$.

For the successful application of ANN, it is necessary to collect as much data as possible. ANN are networks driven by data so that the quality of the model depends on the amount of data; therefore, they are suitable for data fusion. They learn "coaching" in an adequate, created environment.

ANN already have a wide range of application in the real world. Their ability to classify and identify patterns makes them almost ideal in solving many clinical problems. As we know the diagnosis, treatment and outcome prediction in many clinical cases depend on the complex interaction of many clinical, biological and pathological variables, so there is a growing need for analytical tools such as ANN that can perceive the complex relationships between these variables and use these perceptions to get to the correct conclusion (8).

\section{Fuzzy expert system}

Expert systems represent intelligent computer programs that contain "expert" knowledge, that is, knowledge equivalent to that of an expert in the field (8).

Expert systems place knowledge in a knowledge base that is used through illation mechanisms. The obvious advantage of expert systems is that knowledge from various specific areas of study becomes more accessible via computer programs. They cannot completely replace expert people, especially in terms of creativity, and the use of general knowledge (from ordinary life and other fields), but they also have some of the advantages over people, because human knowledge can be lost over time, especially if it is not often used (8).

Fuzzy logic is the field of expert systems. Unlike the formal logic in which the reasoning is done 
with two values (true-false, 0-1), fuzzy logic uses numbers from the interval $[0,1]$, which is much closer to reality, to human thinking and expression. Many phenomena in nature are difficult to describe with only two states that are mutually exclusive. Fuzzy logic allows describing such "imprecise" systems, which is extremely important in medicine because very often only two values cannot be used to describe the condition, quality, but it is necessary to use more of the value (8).

Fuzzy controllers have been designed and implemented to administer vasodilators during surgery, as well as anesthetics $(9,10)$.

\section{Evolutionary computation}

Evolutionary computation (EC) is a general concept for several computer techniques based on natural evolution, that is, the mechanism of natural selection and the survival of the most suitable. Therefore, evolutionary computation can be used to solve real problems. The most common use of EC in medicine is "Genetic Algorithms". The principle is to suggest more solutions to the problem. One set of solutions will remain and "be transferred to a new generation, evolve" and advance, to solutions that will be optimal, and inadequate solutions will be eliminated. Most medical decisions can be formulated as data searches in a very large and complex area. For example, a cytologist who analyzes a cytology sample to decide whether they are malignant or not examines all possible cellular features for a set of functions that allow him to make a clear diagnosis. Genetic algorithms use a natural evolution mechanism to effectively search in a given area. They are applied to perform several types of tasks such as diagnosis and prognosis, medical image and signal processing.

\section{Hybrid intelligent systems}

All listed systems have their advantages and disadvantages so that new artificial systems use more mechanisms, which increases their potential. Their synergy allows a hybrid system that can get clear information from raw data, use human mechanisms of reasoning, can work with imprecise information and learn to adapt to a changing and unknown environment (8).

\section{Application of AI in Medicine}

\section{Diagnostics}

An analysis of disease status involves grading the degree of disease or progression of the disease. The purpose is to improve the accuracy of the treatment decisions and forecasting the prognosis. In order to ensure reproducibility, disease analysis is performed using clear, verbalized observations. Skilled doctors can collect data from patients who do not cooperate adequately. The problem is human inconsistency caused by tiredness $(11,12)$ or blood sugar level $(13,14)$. However, this is not the case with AI.
Bakst was one of the first researchers to explore the clinical potentials of $\operatorname{ANN}(15,16)$. He has developed a neural network model that accurately diagnoses acute myocardial infarction. Since then, ANN has been applied in almost every field of medicine. ANNs were used in clinical diagnosis, in the interplay of radiographs, MRI-magnetic resonance imaging, CT, ultrasound, and wave analysis, electrocardiogram (ECG), electroencephalograms (EEG), interpretation of data in the placement intensive care (8).

Stamei et al. have developed a classification algorithm using neural networks called Prost Asure Index that can classify changes to the prostate as benign or malignant (17). This model was subsequently validated in prospective studies with a diagnostic accuracy of $90 \%$, with a sensitivity of $81 \%$ and a specificity of $92 \%$ (18).

Some of the other relevant ANN applications in diagnosis include abdominal pain and appendicitis (19) retained stone particles in the bile ducts (20) glaucomas (21) and back pain (22).

Fuzzy logic is a data processing methodology that allows ambiguity and is therefore particularly suitable for the application in medicine. Zadeh wrote in 1969 that "the most probable field of application of this theory lies in medical diagnostics and, to a lesser degree, in the description of biological systems (23).

Schneider et al. have shown that fuzzy logic was more precise than multiple logistic regression analysis in lung cancer diagnosis using tumor markers (24). It is also used in the diagnosis of leukemia, cancer, for the characterization of breast ultrasound, MRI brain.

EC and the principles of genetic algorithms are used for the diagnosis of lung cancer (25), computerized analysis of mammographic micro-calcifications (26) for MRI segmentation of brain tumor to measure the efficacy of treatment strategies (27) and to analyze computerized 2-D images for the diagnosis of malignant melanoma (28).

Deep learning, a branch of the developing field of machine learning, has advanced over the past several years. In 2012, a deep convergent neural network, AlecNet (29) showed increased accuracy in the classification of high-resolution images and in 2015, similar versions, including Google's deep neural network GoogLeNetResNet's (30) and deep neural network (31) have exceeded the human limit of image recognition accuracy.

Takahashi et al. in 2017, evaluated an ANN system for disease analysis, which assesses the stage of diabetic retinopathy, and the retina areas that cannot be visualized on the fundoscopy, as well as another system that directly suggests treatments and determines prognoses (32).

Esteve et al. published a paper in 2017 on the classification of skin cancer using deep neural networks. Skin cancer is diagnosed visually. Using AI, processing a series of images in its databases (specifically 129,450 images), more precise classification of skin lesions can be made that represents skin cancer in different stages. Further development in- 
volves the creation of an application that will allow dermatologists to work beyond their specialist offices, which is of great importance in the early screening of skin cancer (33).

Combining of such algorithms with the knowledge and experience of physicians is important. Participants of the International Symposium on Biomedical Imaging have created computer systems for detection of metastatic breast cancer with the help of data obtained via biopsy of the lymph nodes. The winner's algorithm successfully detected cancer with an accuracy of $92.5 \%$. When the pathologist independently examined the same images, the success rate was $96.6 \%$. Combining the prediction of a deep learning system with pathologist diagnostics increased the pathologist's success rate to $99.5 \%$, that is approximately an $85 \%$ reduction of the human error rate (34).

IBM has developed an AI system called Watson. The supercomputer has the ability to quickly review a patient's genetic data to diagnose the disease, which would normally take several weeks. The IBM System Watson has diagnosed a woman who was unsuccessfully treated for acute myeloid leukemia, a rare type of leukemia by comparing the patient's genetic testing and oncological data from over 20 million cases to which it had access (35).

A new project called Deep Mind has a goal to create tools for improving the radiotherapeutic treatment of head and neck cancer. Medicine specialists need 4 hours to inspect the obtained video in detail. Bearing in mind that there are parts of vital importance in that area, it is extremely important that the healthy cells remain intact. By reviewing a large database and applying adequate algorithms, this process would take Deep Mind about an hour to finish, which leaves the physician more time to work with patients (36).

\section{Prevention of disease}

Prevention of disease is an extremely important branch of medicine. With the help of neural networks, patients who have been predisposed to a condition can be identified, and it is possible to focus on them in order to prevent the progress of the disease. It is also possible to predict the survival of patients with breast cancer and colorectal carcinoma $(37,38)$.

When predicting the outcome of treatment for patients in intensive care units, ANN showed better prediction power compared to APACHE IItest for the severity of patients' condition (39).

In a search for a reliable sign that a patient with mild cognitive impairment would suffer from Alzheimer's, experts initiated neuroimaging of brain structures of people with Alzheimer's desease. They have pulled the data from global tests, in which they collected recordings and clinical assessment of patients with mild cognitive impairment. A group of researchers then used AI and big data to develop an algorithm that would recognize dementia two years before the first symptoms. The data they used to teach AI to recognize dementia are amyloid positron emission tomography (PET) of the brain of patients who are prone to developing Alzheimer's disease. After analyzing thousands of PET patient records, the algorithm has managed to recognize which of them are susceptible to dementia with $84 \%$ accuracy $(40)$.

\section{Applications for physicians and patients}

A study conducted in the UK has shown that thousands of patients die in acute renal failure or sepsis due to insufficiently rapid diagnosis. That's why Deep Mind has developed an application that generates patient information and notifies doctors about changes in vital signs, biochemical parameters, without the need for medical staff to review the documentation. This application saves 2 hours of working time to medical staff daily (41).

An application has been developed to monitor patients using antidepressant therapy. It is known that the effects of therapy need to be prolonged for a longer period of time, but with the help of this application, monitoring of the effects of therapy is enabled. The condition of the patient is evaluated more often and in a more efficient manner, which speeds up their recovery. The effects of the therapy can be monitored daily. The test works on smartphones, tablets and any web browser. Patients complete the test within 10-15 minutes, which includes recognizing facial expressions and emotions, and answering a range of health issues, which determine whether there is a shift in therapy (42).

The American Heart Association and the American Society for Infarction of the brain sponsored a web environment for the monitoring of cardiac patients called the Heart360 Cardiovascular Wellness Center. Heart360 allows patients to monitor their blood pressure, blood glucose levels, cholesterol, weight, diet, and physical activity, and on the basis of these data, they receive advice and information specific to their condition. More precisely, patients can collect and record these parameters, set goals, and monitor their progress, review their data in charts that they can print and share with others involved in their family health, receive news and articles of potential interest based on their health information (43).

More than $20 \%$ of the time of the medical staff is spent on data entry. Considering that physicians are overloaded with technical tasks, such as electronic health records, instructions, orders, they have less time for patients, research, mastering new technologies and improving their skills. Radical productivity improvements are needed, in order to maintain the current health standards and to make progress. The combination of human expertise and automated functionality creates a model of "perfect" physician (44).

Immortality is the idea of alchemists since ancient times. Company Insilico medicine has created an algorithm, which can calculate the biological age of any patient based on parameters of their blood. This is the way in which AI can help people, by calculating biological age, to prolong life. This artificial 
neural network is trained by hundreds of thousands of patient data. After the acquired values, a person can change the lifestyle, include certain medications, supplements in the therapy. In a study published in 2018 , the accuracy of the acquired values was tested with this application, and the results showed that blood parameters can be used reliably in determining biological age (45).

The modern world is unimaginable without social networks, where two billion images are published each day. After a study showing that blind people feel outcast and frustrated about the inability to access such content, Facebook has decided to help these people with the help of AI. There are 39 million blind people in the world, and even 246 million have vision disorders. Using AI, which, with the help of algorithms, recognizes visual representation, blind people are enabled to recognize the content of the picture. It is planned that detailed and precise image descriptions will be written in the upper right corner of the photo, which will then be translated into an audio signal, also using the application (46).

Another social network focused on the research of users who potentially have depression. With the help of machine learning and the correlation between the colors of the published images and the mental health of an individual examined, a significant correlation was observed. In addition to colors, the use of contrasts and ace recognition were taken into account, and it was concluded that people with depression do not have a lot of pictures with other people on the profile, which is an indicator of sociality, as well as the number of likes and comments. The researchers have shown that the success of this algorithm is $70 \%$, which is a higher percentage compared to general practitioners' (47).

A new application that is used on the software platform for data analysis processes information from the sensor. This software platform relies on the original algorithm for identifying hand-to-mouth gestures that characterize smoking cigarettes. Observation of smokers while smoking and immediately notification of smokers through the SmokeBeat application led to a reduction in smoking and showed a significant change in the study group regarding the number of cigarettes per day, while the control group did not make any significant changes (48).

\section{Application of AI in Pharmacy}

The application of AI is not only seen in the diagnosis, monitoring, prediction of the disease, but also in the development of new drugs. The use of machine learning, in preliminary (early stages) drug discovery, starts from the initial screening of drugs to the predicted rate of success.

\section{Clinical trials}

Clinical trials of drugs are long-lasting and costly, and machine learning has several useful potential applications in helping to organize clinical trials. The application of an advanced, predictive analysis in identifying candidates for clinical trials, find- ing the best size sample for increased efficiency, adjusting the differences in patient recruitment sites and using electronic medical records to reduce data errors can lead to more efficient and more cost-effective testing.

Machine learning can also be used for remote monitoring and access to real-time data for increased security; for example, monitoring biological and other signals for any sign of injury or death of the participants (49).

\section{Drug design}

The way in which AI is used in the design of new drugs is based on monitoring the interaction of the 3D models of molecules and target sites (receptors, enzymes,...) which can represent possible therapy. This is achieved by the application of deep learning based on the existing behavioral history of the molecules. In other words, just as AI manages to learn how to recognize images - by inspecting thousands of examples of images, it generates potential drugs based on the behavior of the molecules in its base. Different programming companies, in collaboration with scientists from natural sciences, have created an algorithm that detects an interaction between drugs and a broad biological system, which then narrows into smaller groups of activities. It also points out that the testing of tens of millions of cases makes extremely accurate and quick predictions. And that is precisely the key to ensure success in the development of drugs, primarily because AI can scan all possible combinations more quickly and narrow down possible actions. In addition, instead of average 12 years and $\$ 2.9$ billion for drug development, scan results can be obtained in a few weeks with a significant reduction in costs (50).

Last year, a virtual search was launched for safe, existing drugs that could be redesigned to treat the Ebola virus. Two drugs were found through the AI technology of the company that can significantly reduce the Ebola virulence. This analysis, which usually lasts for months or years, was completed in less than one day (51).

\section{Epidemiology}

By using machine learning and AI, the history of the epidemic can be studied, the activity of social media analyzed, and it can be predicted where and when the epidemic can occur with considerable accuracy. The AIME-AI Project in Medical Epidemiology and their platform make it possible to predict the exact geographical location and the date of outbreaks of infectious diseases such as tropical fever or zyka for three months in advance, with a precision of $86.37 \%$. It has been found that 270 changeable factors affect the outbreak of epidemics. An autonomous system was developed so that every 23 seconds it autonomously automatically goes through 270 variables. Some of them are the speed and direction of the wind, the temperature, the movement of the population (52). 


\section{Formulation of Pharmaceutical Preparations}

The application of neural networks as one of the AI technologies is a modern approach to solve the complex problems of formulating pharmaceutical preparations. The application of ANN represents a new dimension in the formulation of pharmaceutical preparations due to unique advantages, such as nonlinearity, the ability to model and optimize with a small number of experiments. ANN have been successfully applied in designing compositions of pharmaceutical preparations, optimizing production processes, providing and controlling quality, predicting the stability of pharmaceutical preparations, in vitro testing the rate of release of the active substance from the pharmaceutical form and in vitro / in vivo correlation. With the development of new, powerful software packages adapted to the user, the application of ANN in the design and development of new pharmaceutical preparations is also foreseen, as well as for the quick and simple assessment of their stability, safety, and efficiency while at the same time significantly reducing costs (1).

\section{Adherence}

The development of medicine is aimed at treating the disease, but without an adequate way and frequency of taking drugs, the success of therapy is, almost certainly, impossible. New technologies in medicine have found application in monitoring of therapy. Chronic therapy adherence is important because chronic diseases such as diabetes, hypertension, have no clear symptoms, so patients can often skip the dose. Studies suggest that $33-50 \%$ of patients do not take medication correctly, which contributes to nearly 100,000 premature deaths each year. Inadequate adherence is the main cause of uncontrolled hypertension, which is the main cause of stroke, coronary heart disease, cardiac insufficiency, and mortality.

To cope with these challenges, researchers have applied AI to develop an adherence model that automatically adjusts the communication of text messages to the individual needs of patients. An adherence monitoring study was conducted in two groups of patients. One group was control and respondents applied a drug from the bottle that had the ability to record the date and time of the opening. The second group was examined and respondents used the same bottle and SMS reminder system. SMS had a motivational content, but content and frequency of messages would automatically be adjusted using AI algorithms. Adjustment of the content is done due to differences in the use/non-use of drugs. It is based on the principle of rewards and punishments, and further content and frequency of messages depend on it. The results showed that the adherence of the investigated group was significantly improved over 3 months, compared to the control group (53).

\section{Application of AI in Genetics}

Genome sequencing is known to be a large, long-lasting venture, which is believed to allow scientists to inspect etiology of numerous diseases. However, no one predicted the enormous amount of data they will receive and which someone will have to process to get useful information. Today, machine learning and hardware help to get to data with computer support, which further accelerates research. It is now known that the causes of various diseases do not lie in the mutation of a single gene, but involve multiple genes, as well as their interaction. The sequencing of the genome that earlier lasted for days has now been shortened for a few minutes, and the information can be used concretely. Genome sequencing is extremely important in early detection of disease, infertility, non-invasive prenatal tests, mental health tests and prediction of genetic therapy, in infectious diseases, and cluster redistribution of Cluster (Clustered Regularly Interspaced Short Palindromic Repeats) genome modification.

\section{Medicine}

Ethical Aspects of applications of AI in

The difference between man and machines and other beings is the ability to think. But, is this still true today? With the development of AI and intelligent agents, it may no longer be the case. Is the man still a "superior" race, and if so, for how long? What is the distinction between man and machine now? Today we can say that these are emotions, conscience, empathy. Again, questions arise, until when? As we could not imagine an agent who will be able to think independently, make decisions, so it is incredible to us today that it is possible that they will have emotions.

It is believed that automation and AI will take over, and over the next 5 years, 7.1 million jobs will be extinguished, mainly in the area of administration and industry. There are various workplaces that are dangerous to people, such as mines, quarries, so replacing them with robots is an exceptional benefit. Also, in different jobs where there is a continuous repetition of actions, due to loss of concentration, injuries, disabilities, even deaths are possible.

The administration is an inevitable obligation for professionals in all areas, but with AI, it is possible to shorten the time spent in performing the bureaucratic chore. This applies, first of all, to medical staff, who need to be dedicated to patients. Such changes would certainly influence the improvement of the quality of health care.

How smart is it to give so much power to agents? It's one thing that they have a picture of the environment themselves, and quite another about the circumstances, aspects of the society in which they occur. The question arises as to whether they will turn against us, whether it will have some devastating tendencies. Such dilemmas have surfaced 
since the time of the invention of dynamite, then the invention of nuclear energy, since they were later used for the purpose of killing people, i.e. warfare. Is a human being a humane being? A man has made various disasters through history, started wars in which millions have dyed, developed new infectious agents, etc.

The drone, which transmits defibrillator to patients with myocardial infarction, was previously mentioned. What happens if there are two simultaneous calls? Is the drone, despite AI, capable of making a decision to help patients? Can we let it make such important decisions? This is just an example, but the ethical question of leaving the decision to intelligent agents pervades all other areas of AI.

When it comes to AI, it is about collecting and procesfourquestions: PAPA (privacy, accuracy, property, accessibility).

Privacy: What information should a person disclose to others, and under what conditions? What can people keep for themselves and not be forced to disclose to others?

Accuracy: Who is responsible for the authenticity, loyalty, and accuracy of the information? Similarly, who will be responsible for information errors?

Ownership: Who owns information? What is the fair "price" for information exchange? Who owns the channels through which information is transmitted?

Accessibility: What information does a person or organization have the right or privilege to obtain, under what conditions and with which safeguards?

Who collects this information, where, in what way? This process is extremely important and responsible because based on this data, the setting of an algorithm will play an important role.

Our moral imperative is clear. We must ensure that the information technology and the information they handle are used to improve the dignity of mankind. In order to achieve these goals, we need to formulate a new social contract, which ensures everyone the right to fulfill their human potential (54).

The data collected must be adequately guarded, as the Data Protection Act requires this. The Deep Mind project is working to analyze 1.6 million patients annually in three hospitals in London in order to analyze and improve radiological healing of the head and neck. Information management has signed a special agreement with a precise data protection plan, regulations, methods of implementation and control, and the possibility for patients to veto the use of their data. There are always concerns about possible hacking incursions or the sale of information.

Google, which is the maker of the Deep Mind project, is one of the most powerful corporations in the world, and it is undoubted that with the development of these projects in healthcare, you will earn huge amounts of money. If this improves health care and helps save lives and treatments, then this is not a moral issue, because human health is imperative about which there is no dilemma. The real question is not to allow hospitals to become dependent on the technology of one of the most powerful companies in the world.

Use of AI is impossible without complex softwares, hardwares, cameras and other sensory systems, or smartphones. Such devices are not available in all countries of the world due to lack of money. Is it necessary to develop new technologies, while in some parts of the world there is still a shortage of food, water, basic livelihoods, where there is a high percentage of illiterate people suffering from a wide range of illnesses? The difference in economic status and the way of life of people in different parts of the world has always been a big gap, and there are chances that it will be even greater, using AI.

Social networks have possibilities to investigate people's interests. Based on searched products, which sometimes can be drugs, psychoactive substances, plants, herbal products, people's interests can be analyzed. Collected data are important for marketing of companies which produce those products. Advertisings are presented to other people in, for example, the same social network groups. Social groups usually consist of people of similar age, sex, interests, but they are not the same health status. If advertised products are health products, it is dangerous, because the same products are not safe for every person. This can lead to many adverse effects and intoxications. 


\section{References}

1. Ibrić $S$, Knežević M, Parojčić J, Đurić Z. Primena veštačkih neuronskih mreža u formulaciji farmaceutskih preparata. Arh farm 2007;57:399-414.

2. Lusted LB. Medical electronics. N Engl J Med 1955;252 (14):580-5. [CrossRef] [PubMed]

3. Miladinovic $M$, Mihailovic $B$, Mladenovic $D$, Duka $M$, Zivkovic D, Mladenovic $S$, et al. Artificial intelligence in clinical medicine and dentistry. Vojnosanit Pregl 2017; 74(3):267-72.

4. World Health Organization. Diabetes. "cited 2019 Feb 15"; Available from:

http://www.who.int/mediacentre/factsheets/fs312/en/

5. National Cancer Institute. Cancer statistics. "cited 2019 Feb 15"; Available from:

https://www.cancer.gov/about-cancer/understanding/ statistics

6. HIV. Global statistics. "cited 2019 Feb 12"; Available from: https://www.hiv.gov/hiv-basics/overview/dataand-trends/global-statistics

7. Gunn AA. The diagnosis of acute abdominal pain with computer analysis. J R Coll Surg Edinb 1976;21(3): 170-2. [PubMed]

8. Ramesh AN, Kambhampati C, Monson JRT, Drew PJ. Artificial intelligence in medicine. Ann R Coll Surg Engl 2004; 86(5):334-8. [PubMed]

9. Ying $H$, McEachern M, Eddleman DW, Sheppard LC. Fuzzy control of mean arterial pressure in postsurgical patients with sodium nitroprusside infusion. IEEE Trans Biomedical Eng 1992; 39(10):1060-70. [CrossRef] [PubMed]

10. Mason DG, Ross JJ, Edwards ND, Linkens DA, Reilly CS. Self-learning fuzzy control of atracurium-induced neuromuscular block during surgery. Med Biol Eng Comput 1997; 35(5):498-503. [CrossRef] [PubMed]

11. Gilbert DT. How mental systems believe. Am Psychol 1991;46(2):107-119. [CrossRef] [PubMed]

12. Macrae CN, Bodenhausen GV. Social cognition: thinking categorically about others. Annu Rev Psychol 2000; 51:93-120. [CrossRef] [PubMed]

13. Danziger S, Levav J, Avnaim-Pesso L. Extraneous factors in judicial decisions. Proc Natl Acad Sci USA 2011;108(17):6889-92. [CrossRef] [PubMed]

14. Gailliot MT, Baumeister RF, DeWall CN, Maner JK, Plant EA, Tice DM, et al. Self-control relies on glucose as a limited energy source: willpower is more than a metaphor. J Pers Soc Psychol 2007; 92(2):325-36. [CrossRef] [PubMed]

15. Baxt WG. Use of an artificial neural network for data analysis in clinical decision-making: the diagnosis of acute coronary occlusion. Neural Comput 1990; 2(4): 480-9. [CrossRef]

16. Baxt WG, Skora J. Prospective validation of artificial neural network trained to identify acute myocardial infarction. Lancet 1996;347(8993):12-5. [CrossRef] [PubMed]

17. Stamey TA, Barnhill SD, Zang Z. Effectiveness of ProstAsureTM in detecting prostate cancer (PCa) and benign prostatic hyperplasia (BPH) in men age 50 and older. J Urol 1996; 155:436A.

18. Babaian RJ, Fritsche HA, Zhang Z, Zhang $\mathrm{KH}$, Madyastha KR, Barnhill SD. Evaluation of prostAsure index in the detection of prostate cancer: a preliminary report. Urology 1998; 51(1):132-6.

[CrossRef] [PubMed]

19. Pesonen E, Ohmann C, Eskelinen M, Juhola M. Diagnosis of acute appendicitis in two databases. Evalua- tion of different neighborhoods with an LVQ neural network. Methods Inf Med 1998; 37(1):59-63.

[CrossRef] [PubMed]

20. Golub R, Cantu R Jr, Tan M. The prediction of common bile duct stones using a neural network. J Am Coll Surg 1998; 187(6):584-90. [CrossRef] [PubMed]

21. Henson DB, Spenceley SE, Bull DR. Artificial neural network analysis of noisy visual field data in glaucoma. Artif Intell Med 1997; 10(2):99-113.

[CrossRef] [PubMed]

22. Bounds DG, Lloyd PJ, Mathew BG. A comparison of neural network and other pattern recognition approaches to the diagnosis of low back disorders. Neural Networks 1990; 3(5):583-91. [CrossRef]

23. Zadeh LA. Biological application of the theory of fuzzy sets and systems. In: Proceedings of the International Symposium on Biocybernetics of the Central Nervous System. Boston: Little Brown, 1969; 199-212.

24. Schneider J, Bitterlich N, Velcovsky HG, Morr H, Katz $\mathrm{N}$, Eigenbrodt E. Fuzzy-logic based tumor-marker profiles improved sensitivity in the diagnosis of lung cancer. Int J Clin Oncol 2002; 7(3):145-51.

[CrossRef] [PubMed]

25. Jefferson MF, Pendleton N, Lucas SB, Horan MA. Comparison of a genetic algorithm neural network with logistic regression for predicting outcome after surgery for patients with nonsmall cell lung carcinoma. Cancer 1997; 79(7):1338-42. [CrossRef] [PubMed]

26. Chan HP, Sahiner B, Lam KL, Petrick N, Helvie MA, Goodsitt MM, et al. Computerized analysis of mammography microcalcifications in morphological and texture feature spaces. Med Phys 1998; 25(10):200719. [CrossRef] [PubMed]

27. Velthuizen RP, Hall LO, Clarke LP. Feature extraction for MRI segmentation. J Neuroimaging 1999; 9(2): 85-90. [CrossRef] [PubMed]

28. Handels $H$, Ro $\beta T$, Kreusch J, Wolff $H H$, Pöppl SJ. Feature selection for optimized skin tumor recognition using genetic algorithms. Artif Intell Med 1999; 16(3): 283-97. [CrossRef] [PubMed]

29. Krizhevsky A, Sutskever I, Hinton Ge. ImageNet classification with deep convolutional neural networks. Communications of the ACM 2017; 60(6):84-90. [CrossRef]

30. Szegedy C, Liu W, Jia Y, Sermanet P, Reed S, Anguelov D, et al. Going deeper with convolutions. Proceedings of the IEEE Conference on Computer Vision and Pattern Recognition; 2015 June 7-12; Boston, USA: CVPR; 2015. [CrossRef]

31. He K, Zhang $X$, Ren S, Sun J. Deep residual learning for image recognition. Proceedings of the IEEE Conference on Computer Vision and Pattern Recognition; 2016 Jun 27-30; Las Vegas, USA: CVPR; 2016. [CrossRef]

32. Takahashi $H$, Tampo $H$, Arai $Y$, Inoue $Y$, Kawashima $H$. Applying artificial intelligence to disease staging: Deep learning for improved staging of diabetic retinopathy. PLoS One 2017; 12(6): e0179790. [CrossRef] [PubMed]

33. Esteva A, Kuprel B, Novoa RA, Ko J, Swetter MS, Blau $\mathrm{HM}$, et al. Dermatologist-level classification of skin cancer with deep neural networks. Nature 2017; 542(7639):115-8. [CrossRef] [PubMed]

34. Beck AH, Gargeya R, Irshad H, Khosla A, Wang D. Deep Learning for Identifying Metastatic Breast Cancer. arXiv preprint 2016; 1606.05718. 
35. Zauderer MG, Gucalp A, Epstein AS, Seidman AD, Caroline A, Granovsky S. Piloting IBM Watson Oncology within Memorial Sloan Kettering's regional network. J Clin Oncol 2014; 32(Suppl 15):e17653. [CrossRef]

36. Nikolov S, Blackwell S, Mendes R, De Fauw J, Meyer C, Hughes C, et al. Deep learning to achieve clinically applicable segmentation of head and neck anatomy for radiotherapy. ArXiv preprint 2018;1809.04430v1.

37. Burke HB, Goodman PH, Rosen DB, Henson DE, Weinstein JN, Harrell FE Jr, et al. Artificial neural networks improve the accuracy of cancer survival prediction. Cancer 1997; 79(4):857-62.

[CrossRef] [PubMed]

38. Burke HB, Hoang A, Iglehart JD, Marks JR. Predicting response to adjuvant and radiation therapy in patients with early stage breast carcinoma. Cancer 1998; 82 (5):874-7. [CrossRef] [PubMed]

39. Dybowski R, Weller P, Chang R, Gant V. Prediction of outcome in critically ill patients using artificial neural network synthesised by genetic algorithm. Lancet 1996; 347(9009):1146-50. [CrossRef] [PubMed]

40. Salvatore C, Cerasa A, Battista P, Gilardi MC, Quattrone A, Castiglioni I. Magnetic resonance imaging biomarkers for the early diagnosis of Alzheimer's disease: a machine learning approach. Front Neurosci 2015; 9:307. [CrossRef] [PubMed]

41. James Vincent Google is absorbing DeepMind's health care unit to create an 'AI assistant for nurses and doctors'. "cited 2019 Feb 20"; Available from:

https://www.theverge.com/2018/11/13/18091774/go ogle-deepmind-health-absorbing-streams-team-aiassistant-nurse-doctor

42. Innovate UK grant helps fund research into depression treatment. "cited 2019 Feb 11"; Available from: https://www.med-technews.com/news/innovate-ukgrant-helps-fund-research-into-depression-treatm/

43. Sourla E, Sioutas S, Syrimpeis V, Tsakalidis A, Tzimas G. CardioSmart365: Artificial intelligence in the service of cardiologic patients. Advances in artificial intelligence 2012; 585072. [CrossRef]

44. Stocker J. Artificial intelligence is coming to medicinedon't be afraid. "cited 2018 Feb 20"; Available from: https://www.statnews.com/2017/08/18/artificialintelligence-medicine/
45. Mamoshina $P$, Kochetov $K$, Putin E, Cortese F, Aliper A, Lee WS, et al. Population specific biomarkers of human aging: a big data study using South Korean, Canadian and Eastern European patient populations. J Gerontol A Biol Sci Med Sci 2018; 73(11):1482-90. [CrossRef] [PubMed]

46. García D, Paluri M, Wu S. Under the hood. Building accessibility tools for visually impaired on Facebook. "cited 2018 Feb 11"; Available from: https://code.facebook.com/posts/457605107772545/ under-the-hood-building-accessibility-tools-for-thevisually-impaired-on-facebook/

47. Reece AG, Danforth CM. Instagram photos reveal predictive markers of depression. EPJ Data Science 2017; 6:15. [CrossRef]

48. Dar R. Effect of real-time monitoring and notification of smoking episodes on smoking reduction: A pilot study of a novel smoking cessation app. Nicotine Tob Res 2018; 20(12): 1515-8. [CrossRef] [PubMed]

49. Fagella D. 7 Application of Machine Learning in Pharma and Medicine. "cited 2019 Feb 10"; Available from:

https://www.techemergence.com/machine-learningin-pharma-medicine/

50. Khamis MA, Gomaa W, Ahmed WF. Machine learning in computational docking. Artif Intell Med 2015; 63 (3):135-52. [CrossRef] [PubMed]

51. Kugelman JR, Sanchez-Lockhart M, Andersen KG, Gire S, Park DJ, Sealfon R, et al. Evaluation of the potential impact of Ebola virus genomic drift on the efficacy of sequence-based candidate therapeutics. MBio 2015; 6(1):e02227-14. [CrossRef] [PubMed]

52. Furtkamp J. Could AI Help Us Predict the Next Epidemic? "cited 2018 Feb 15"; Available from: https://reliefweb.int/report/world/could-artificialintelligence-help-us-predict-next-epidemic Written.

53. Agency for Healthcare Research and Quality (AHRQ). Improving Adherence and Outcomes by Artificial Intelligence-Adapted Text Messages (AIM@BP). "cited 2018 Feb 10"; Available from: https://clinicaltrials.gov/ct2/show/NCT02454660

54. Mason R. Four ethical issues of the information age. Management Information Systems Quarterly 1986; 10 (1):5-12. [CrossRef] 


\title{
PRIMENA VEŠTAČKE INTELIGENCIJE U MEDICINI I FARMACIJI - ETIČKI ASPEKTI
}

\author{
${ }^{1}$ Univerzitet u Nišu, Medicinski fakultet, Niš, Srbija \\ ${ }^{2}$ Zavod za sudsku medicinu Niš, Niš, Srbija \\ ${ }^{3}$ Klinika za neurologiju, Klinički centar Niš, Niš, Srbija \\ Kontakt: Emilija Kostić \\ Bulevar dr Zorana Đinđića 81, 18000 Niš, Srbija \\ E-mail: emilija293@gmail.com
}

Emilija J. Kostić1,2, Dimitrije A. Pavlović ${ }^{1}$, Miroslava D. Živković1,3

Poslednjih 30 godina zabeležen je razvoj veštačke inteligencije, čije se dobrobiti mogu primeniti u skoro svim oblastima nauke i života. Od sredine prošlog veka, istraživači su otkrili potencijalne primene (tehnika veštačke inteligencije) u svakom polju medicine. Važnost veštačke inteligencije ogleda se u mogućnosti pravilnog odlučivanja, bez subjektivnosti, bez umora, sa neograničenim mogućnostima upoređivanja, pamćenja i zaključivanja. Ovo je veoma važno u medicini, za prevenciju i dijagnostiku različitih oboljenja, kao i za praćenje efekata terapije. Brojne studije pokazale su da će uskoro veštačka inteligencija zameniti medicinske radnike u brojnim aktivnostima, jer su rezultati dobijeni primenom veštačke inteligencije bolji i precizniji. Razvijene su brojne aplikacije koje bolesnicima pojednostavljuju pridržavanje terapije, čime se poboljšava adherenca i u konačnome efekat terapije. Primena veštačke inteligencije zastupljena je i u farmaceutskoj industriji, u dizajnu novih lekova. Ovim se skraćuju pretklinička ispitivanja, koja su izuzetno duga i skupa. Veštačka inteligencija donosi zaključke na osnovu podataka koji su joj dati, pa se mora voditi računa o validnosti tih podataka, jer se na osnovu njih razvijaju izuzetno bitni algoritmi. Važan je aspekt zaštita podataka o bolesnicima, jer je mogućnost objavljivanja tih podataka veliki etički problem. Zbog računara i veštačke inteligencije već mnogo ljudi gubi posao širom sveta, a postoji tendencija nastavka ovakvog trenda. Pitanje je da li je potrebno da mašine zamene ljude u oblasti kao što je medicina, gde su osećanja, empatija i toplina vrlo važni faktori.

Acta Medica Medianae 2019;58(3):128-137.

Ključne reči: veštačka inteligencija, medicina, farmacija, primena, etika 